\title{
Implementation of the Constitutional Law on Judicial Protection
}

\author{
${ }^{1}$ Damir Kh. Valeev, ${ }^{2}$ Anas G. Nuriev, ${ }^{3}$ Rafael V. Shakirjanov \\ ${ }^{1-3}$ Kazan Federal University \\ Email:valeev55@gmail.com,anasnuriev@yandex.ru,rakat51@mail.ru
}

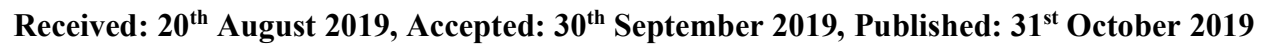

\begin{abstract}
In the presented article, the issue of the importance of translations in the implementation of language guarantees in civil procedural relations and the role of the translator in providing these guarantees is considered. As a result of the study, it was found that the translation in civil procedural relations is considered to be the activity of a special subject - a translator. During the trial, the specified entity is given a special procedural status due to the fluency in the language of the proceedings and the language whose knowledge is necessary for translation. An analysis of the legislative provisions formulated in the civil procedural legislation, and in case of their absence, by analogy of the law borrowed from other procedural sources, allows us to identify two criteria that a translation must meet as a result of the activities of an interpreter, which can be laid in the basis of the motivational part of the court decision. The study of the meaning of translation in civil matters has an important social point of view in terms of the implementation of the constitutional right to use the native language.
\end{abstract}

Keywords

State Language; The State Language of the Subject of the Russian Federation; Judicial Defense; Administration of Justice in the State Language of the Subject of the Russian Federation.

\section{Introduction}

Legislative consolidation of "language guarantees" is provided by the Constitution of the Russian Federation [1]. In particular, part 2 of Article 26 of the Constitution of the Russian Federation determines that everyone has the right to use their native language, to freely choose the language of communication, education, training and creativity. This provision is specified in industry legislation governing the administration of justice. So, according to Part 2 of Art. 9 Code of Civil Procedure of the Russian Federation [2] to persons participating in the case and not knowing the language of the civil proceedings, the right to explain, conclude, make statements, petitions, file complaints in their native language or in any freely chosen language of communication is explained and secured also use the services of a translator. The legislator recognizes violations in the language sphere as violations of the fundamental principles of legal proceedings and in accordance with paragraph 3 of part 4 of Art. 330 Code of Civil Procedure of the Russian Federation are an unconditional basis for the cancellation of the decision of the court of first instance and the transition to consideration of the case according to the rules of the court of first instance without taking into account the particularities of the appeal proceedings.

The objectives of civil proceedings are the correct and timely consideration and resolution of a civil case [3,4,5,6,7]. Of great importance for making a lawful and justified decision is the court's investigation of all the evidence presented by the parties, in terms of their relevance and admissibility. The translation, being the activity of a translator, does not create new evidence, however, it is taken into account by the court when making the decision. In this case, if the court decision is appealed to the court of appeal, the facts investigated by the court of first instance are also checked, however, this does not apply to a transfer that is not re-checked and taken into account by the courts of the verification instances without subsequent checks. This is due to the fact that a deliberately correct, undistorted translation is presumed as a result of the translation procedure, which allows the court to directly evaluate the investigated evidence. All this determines the importance of translation as an important tool for the implementation of the constitutional right to judicial protection.

\section{Methods}

The methodological basis of the study was the general provisions of the science of civil procedural law, administrative procedural law, criminal procedural law. In the study, the following methods of scientific knowledge were used: interdisciplinary, dialectical, sociological method.

\section{Results}

As a result of the study, indicators were established, the analysis of which allows us to establish the current state and prospects for the development of the implementation of the constitutional right to judicial protection in civil cases in the state languages of the constituent entities of the Russian Federation in order to identify the potential of the state language of the constituent entity of the Russian Federation in law enforcement using the example of civil proceedings. 


\section{Discussion}

Dictionary S.Yu. Ozhegova's translation is defined as text translated from one language to another [8, p. 501]. However, the understanding of the translator as a specialist in the philological sense does not correspond to the legal content, since the legislation distinguishes separately a specialist, the result of which is consultation (for example, Article 188 of the Civil Procedure Code) and separately a translator.

Despite the importance of translation, the Code of Civil Procedure of the Russian Federation does not have a legal definition of translation as a result of the activities of a translator and there is no legal definition of the status of a translator as a participant in procedural relations. For comparison, we can cite the definitions established in other procedural sources.

Analysis of procedural sources showed that in all procedural sources there is no definition of translation as a procedural document. The criterion of free language proficiency as determining for the translator is specified in Art. 59 of the Code of Criminal Procedure of the Russian Federation [9], according to this norm, the translator is a person who is involved in criminal proceedings in cases provided for by this Code, who is fluent in a language whose knowledge is necessary for translation. The most complete is the definition of a translator given in Art. 52 CAS RF [10], as a person fluent in the language in which administrative proceedings are conducted, and in another language, knowledge of which is necessary for translation from one language to another, or a person fluent in the technique of communication with the deaf, dumb, deaf and dumb.

In all procedural sources, the main criterion characterizing the translator is fluency in the language of the proceedings and the language whose knowledge is necessary for the translation. At the same time, the legislation does not provide for determining the level of free language proficiency through the establishment of minimum requirements for a translator. Moreover, there are no additional requirements, for example, related to the presence of special education or membership in a self-regulatory organization of judicial translators.

One can only meet an indirect assessment of the competence of a translator in the Code of Criminal Procedure of the Russian Federation. According to Part 2 of Art. 69 of the Code of Criminal Procedure of the Russian Federation, a challenge to a translator can be declared by the parties, and in case of incompetence of a translator, also by a witness, expert or specialist. However, the criteria of incompetence are not specified in the criminal procedure law. In all other procedural sources, an interpreter may be challenged on general procedural grounds.

In order for the translation to receive procedural status and could be laid in the basis of the motivating part of the court decision, it is necessary to involve in the process a person who facilitates the administration of justice as an interpreter on the initiative of persons participating in the case or on their own initiative of the court. Further, the procedural rights and obligations are explained to the person involved. But it is from the moment the translator is warned of responsibility, for the knowingly incorrect translation and that he subscribes to the protocol of the court session, the translator's actions begin to be considered as procedural, acquire a public character and the presumption of their proper nature begins to apply to the results of the translation.

In order for a person to be involved in facilitating the administration of justice, in addition to the general requirements for procedural capacity, compliance with the provision is also required according to which a person participating in a case cannot be involved in a transfer. In particular, other participants in the process are not entitled to assume the duties of a translator, even if they possess the languages necessary for the translation (similar requirements are contained in part 3 of article 52 of the Code of Criminal Procedure of the Russian Federation). At the same time, these persons have the right to use their knowledge to monitor the work of the translator and, in case of their incompetence, to inform the court about this, and subsequently declare the challenge to the translator because of their incompetence. Through these actions, these individuals, in turn, contribute to the administration of justice. In addition, the failure of persons participating in the case to the court to report on incompetence detected, and possibly on the knowingly false translation of the translator by the court, can subsequently be regarded as an abuse of the right of these persons.

It should be noted that civil procedural legislation is indifferent to the consequences of an incorrect translation. Regardless of whether the incorrect translation took place due to the deliberate actions of the translator or because of his incompetence, these actions are qualified by law as a violation of the rules on the language and entail, as indicated above, the cancellation of the decision of the court of first instance with a re-examination of the case.

Thus, considering the issue of the implementation of language guarantees in civil procedural relations, the translator becomes the key figure and the result of his activity is the translation. Based on the study, it was found that in all procedural sources: firstly, there is no legal definition of translation and its significance in procedural relations; secondly, the main criterion characterizing the translator is fluency in the language in which the proceedings are conducted and the language whose knowledge is necessary for the translation. At the same time, the legislation does not provide for determining the level of free language proficiency through the establishment of minimum requirements for a translator.

Meanwhile, when resolving civil disputes, persons who do not fully or completely do not know the language in which the case is being considered also participate. The foregoing also indicates that the norms enshrined in the Constitution of the Russian Federation on the right of citizens to use their native language, in particular in the field of legal proceedings, are implemented through the participation of an interpreter in resolving civil disputes. It follows that the translator not only assists the court in resolving disputes, but also performs a socially significant task of realizing the rights of citizens to use their native language and in the judiciary. 
The foregoing indicates the importance of the procedural figure of the translator and the result of his translation activities with a view to further legislatively determining his status and the significance of the result of his activities in the Code of Civil Procedure of the Russian Federation. It seems that Art. 162 of the Code of Civil Procedure of the Russian Federation must be supplemented with a corresponding sentence and part 1 of this article should be stated as follows: "A translator is a person who is involved in a case by a court in cases provided for by this Code and who is fluent in the language of the civil proceedings, and another language, the knowledge of which is necessary for translation from one language to another, or fluent in communicating with the deaf, dumb, deaf and dumb, contributes to the administration of justice".

\section{Conclusions}

Based on the study, it was found that the translation in civil procedural relations is considered to be the activity of a special subject - a translator. During the trial, the specified entity is given a special procedural status due to the fluency in the language of the proceedings and the language whose knowledge is necessary for translation. An analysis of the legislative provisions formulated in the civil procedural law allows us to identify the criteria that a translation must meet as a result of the activities of the translator, which can be laid in the basis of the motivational part of the court decision.

\section{Acknowledgements}

The work is performed according to the Russian Government Program of Competitive Growth of Kazan Federal University.

The reported study was funded by RFBR according and the Government of the Republic of Tatarstan to the research project № 18-411-160004 r_a.

\section{References}

1. The Constitution of the Russian Federation // Russian newspaper of December 25, 1993

2. Civil Procedure Code of the Russian Federation of November 14, 1992 // FL of the Russian Federation. - dated November 18, 2002. - No. 46. - Art. 4532

3. Damir Kh. Valeev, Anas G. Nuriev., Rafael V. Shakirjanov Implementación del derecho constitucional a la protección judicial en los idiomas estatales del sujeto de la Federación Rusa // Revista Dilemas Contemporáneos: Educación, Política y Valores. - Año: VI. - Número: Edición Especial. - Artículo no.: 24. Período: Diciembre 2018.

4. Nuriev A.G., Khodzhiev A.R, Procedural guarantees of rights of citizens of the Russian federation in the foreign states//Research Journal of Applied Sciences. - 2015. - Vol.10, Is.12. - P.832-834.

5. Safin Z.F. Legal Issues Supporting Production and Distribution of Biotech Products / E. V. Luneva, Z. F. Safin // International journal of Advanced biotechnology and Research. - 2016. - Vol. 7. - № 4. - P. 1260-1264.

6. Valeev D.K., Golubtzov V.G. Modernization of the Russian law: a review of the laws on enforcement proceedings // Life Science Journal. 2014. №11 (8 p.). P. 234-238.

7. Anas G. Nuriev. Características de la Responsabilidad Civil del Notario // Revista Dilemas Contemporáneos: Educación, Política y Valores. - Año: VI. -Número: Edición Especial. - Artículo no.: 31. - Período: Diciembre 2018.

8. S.Yu., Shvedova N.Yu. Explanatory Dictionary of the Russian Language - M.: Azbukovnik, 1999, 994 p.

9. The Code of Criminal Procedure of the Russian Federation of December 18, $2001 / /$ FL of the Russian Federation of December 24, 2001 No. 52 (Part One). Art. 4921

10. Code of Administrative Procedure of the Russian Federation of March 08, 2015 // FL of the Russian Federation. - March 09, 2015. - No. 10. - Art. - 1391. 